\title{
Art of War and Its Implications on Marketing Strategies: Thinking like a Warrior
}

\author{
Filiz Bozkurt ${ }^{\mathrm{a}}$, Ahu Ergen ${ }^{\mathrm{b}}$ \\ ${ }^{a} \mathrm{PhD}$, Doğuş University, İstanbul, Turkey \\ ${ }^{b} \mathrm{PhD}$, Bahçeşehir University, Istanbul, Turkey
}

\begin{abstract}
Throughout the evolution of marketing, as a result of increasing competition, there has been a shift from a production oriented approach to a marketing oriented approach. Strategic thinking that gives companies an advantage over their competitors gained importance. By the end of the 1980s, experts studying strategy looked back into rich military literature to find some basic principles to help them define strategies for today's business environment. In this period warfare and its similarities with the business world were a great inspiration for marketers. The aim of this study is to show the relation between marketing strategies and military strategies. This exploratory research used secondary data. It is expected that, in the twenty-first century's highly competitive conditions, this study will give marketers a different point of strategic view and contribute to marketing literature.
\end{abstract}

Keywords: military strategies, marketing strategies, marketing warfare

JEL Code : M 31

\section{2014 Published by SSBFNET}

\section{Introduction}

Three main periods can be observed in the evolution of marketing. These are the production oriented period, the sales oriented period and the marketing oriented period (Keith, 1960). During the production oriented period that prevailed until the 1930s, corporations were in the "I will sell whatever I produce" mindset because demand was higher than supply. Between 1930 and 1950, with the increased number of firms in the market, they had to focus on sales activities to get their products sold. A marketing oriented approach was adopted after 1950, and there have been significant developments in the field of strategic marketing since then. The number of studies on marketing strategies also increased in the 1980s when competition became intense. Porter (1996) defined strategy as "creating a unique and valuable position that consists of a series of activities." In order for a firm to have a strategy it needs to have different 
activities than its competitors or to conduct similar activities in different ways (Kotler and Keller, 2009). Strategy is also defined as the basic preference of a company, showing where and why it will invest its resources depending on the internal and external environmental conditions and in accordance with its mission and vision (Koçel, 2010). There are many classifications of marketing strategies in the literature (İslamoğlu, 2008; Tek, 1999). Prominent classifications are: market leader, challenger, follower and niche market strategies, defense strategies that can be applied by leaders, offense strategies for challenger firms according to their position in the market; intense growth, stagnant growth, intermittent growth, protecting position, downsizing and harvest strategies according to growth goals; market penetration, product development, market development and diversification strategies, generic strategies (cost leadership, differentiation, focusing) according to the path chosen for growth. On the other hand, fighting on the same ground is not always the only way to success in the marketing world. Blue Ocean Strategy, which was introduced by W. Chan Kim and Renee Mauborgne in 2004 should also be taken into account while defining a strategy. This strategy is about creating a new market and making the competition irrelevant (Ergen, 2011).

\section{Theoretical Framework}

\subsection{Art of War and Its Implications on Marketing Strategies}

\section{An Overview Of Military Strategies}

The development of military strategies goes back to thousands of years. The oldest source on this subject is The Art of War, written by Chinese general and philosopher Sun Tzu on military strategies in sixth century BC (Ho and Choi, 1997). The book was written with "the winning without fighting" approach and contains numerous aspects of war, including the planning stage, where internal and external conditions are analyzed, as well as sections on waging war, tactics, energy, opportunism, maneuvering, changing tactics, marching, terrain, nine kinds of battle grounds, attack with fire, the use of spies and intelligence (Ilicak and Özgül, 2005). The 36 Secret Strategies of the Martial Arts was inspired by Far Eastern martial arts and listed the methods that can be used in advantageous and disadvantageous situations (Moriya, 2008). These strategies are mostly based on deluding the enemy (Pheng and Sirpal, 1995). On the other hand, Prussian General Carl von Clausewitz's "On War" (1989) focuses on the unexpected, dynamic nature of military situations and emphasizes the importance of the flexibility principle in strategy (Garsombke, 1987).

\section{Counterparts Of Military Strategies In Marketing}

While business professionals have long been using terms such as 'price wars,' 'market seizure' and 'armament competition' for market competition, scholars started seeing marketing as a war in the early 1980s. Oxenfeldt and Moore (1978) defined the market as "the battlefield where firms are fighting to seize consumers" and asserted that the need for businesses to develop competitor oriented strategies in order to gain market share will push managers towards military science.

\subsection{The Art of War and Marketing Strategies}


Sun Tzu is the leading name in most studies on the relationship between marketing strategies and warfare. Many of the subjects that the Chinese philosopher considered in his book The Art of War can be adapted to the field of marketing. For instance, the stage of evaluating the conditions suggested by Sun Tzu is very similar to the SWOT analysis used by businesses in the strategic management process. Sun Tzu divides the environment into two categories: partially controllable factors and uncontrollable factors. The battlefield is a partially controllable factor, while weather conditions are an uncontrollable factor in the strategy literature, as it is in economics and policy literature (MacDonald and Neupert, 2005). Before deciding on their strategies, corporations should comprehensively analyze internal and external conditions and shape their strategies accordingly, as do parties of a war (Ilıcak and Özgül, 2005). The counterparts of the concepts offered by Sun Tzu's work in marketing are given in Table 1 (Ho and Choi, 1997).

Table 1. Counterparts of the concepts of Sun Tzu's The Art of War in the field of marketing

\begin{tabular}{|l|l|}
\hline Sun Tzu The Art of War & Marketing \\
\hline Laying a plan & Strategic planning \\
\hline Waging a war & Marketing budget \\
\hline Offensive Strategy & Marketing strategy \\
\hline Tactics & Marketing tactics \\
\hline Energy & Integrated marketing \\
\hline Opportunism & Portfolio management \\
\hline Maneuvering & Changing tactics \\
\hline Marching & Aggressive marketing strategies \\
\hline Terrain & Market field and market segmentation \\
\hline The nine battlefields & Positioning \\
\hline Attack by fire & Use of aggressive marketing tools \\
\hline Use of spies & Use of marketing information system \\
\hline
\end{tabular}

Another study that compares military strategies and marketing strategies emphasized the similarities between these two disciplines. The similarities are given in Table 2 (Ho and Choi, 1997).

Table 2. Similarities between Sun Tzu and Davidson's ideas 


\begin{tabular}{|l|l|}
\hline Sun Tzu - The Art of War & Huge Davidson - Offense Marketing \\
\hline $\begin{array}{l}\text { Offensive Strategy } \\
\text { The aim of war is not only to win, but also to } \\
\text { make profit. }\end{array}$ & $\begin{array}{l}\text { Profitable } \\
\text { There should be a balance between the firm's } \\
\text { need for profit and the consumer's need for value. }\end{array}$ \\
\hline $\begin{array}{l}\text { Opportunism } \\
\text { Whoever arrives at the battlefield first can take } \\
\text { initiative. }\end{array}$ & $\begin{array}{l}\text { Offensive } \\
\text { The firm should lead the market and leave its } \\
\text { competitors in the position of followers. }\end{array}$ \\
\hline $\begin{array}{l}\text { The Power of Defense/Energy } \\
\text { The internal structure has to be strengthened for } \\
\text { defense. }\end{array}$ & $\begin{array}{l}\text { Integrated } \\
\text { To achieve better results armies should cooperate. } \\
\text { institution. }\end{array}$ \\
\hline $\begin{array}{l}\text { Planning } \\
\text { The environment and the competitors should be } \\
\text { comprehensively analyzed before planning. }\end{array}$ & $\begin{array}{l}\text { Analysis is crucial for a winning strategy. } \\
\text { Analys the whole }\end{array}$ \\
\hline $\begin{array}{l}\text { Fighting } \\
\text { When war is decided, action should be taken } \\
\text { quickly. }\end{array}$ & $\begin{array}{l}\text { Effective Application } \\
\text { Applied daily in a powerful and disciplined } \\
\text { manner. }\end{array}$ \\
\hline
\end{tabular}

Source: Ho, S.K. and Choi, S.F.A. (1997). Achieving marketing success through Sun Tze's Art of Warfare. Marketing Intelligence \& Planning, 15(1), 38-47.

Marketing studies that refer to military literature use various classifications for military strategies. In "The Art of War", the basic war strategies are: defense, offense, flanking offense and guerilla (Garsombke, 1987). In marketing warfare, defensive strategy is appropriate for the leader, while offense is for challengers. Flank strategy is for firms aiming at certain market segments, and guerilla strategy is good for small firms (Tino,1987). Meanwhile, in their article titled "Marketing Warfare in the 1980s," Kotler and Singh (1981) looked at marketing warfare strategies in two groups: defensive and offensive strategies. In an article published anonymously on the internet, the most effective military strategies in history are said to be the crescent strategy, shock and awe, blitzkrieg and guerilla warfare(www.frmtr.com), all of which can be considered offensive strategies.

Table 3. Defensive and offensive strategies

\begin{tabular}{|l|l|}
\hline Defensive Strategies & Offensive Strategies \\
\hline Position Defense & Frontal Attack \\
\hline Mobile Defense & Flanking Attack \\
\hline Preemptive Defense & Encirclement \\
\hline Flank Positioning Defense & Bypass Attack \\
\hline Counteroffensive Defense & Guerilla Warfare \\
\hline Strategic Withdrawal & \\
\hline
\end{tabular}

Source: Kotler, P. and Singh, R. (1981). Marketing warfare in the 1980's. Journal of Business Strategy, 1(3): 30-41. 
The rest of this study will be based on the defensive and offensive strategies from the military literature that Kotler and Singh (1981) adapted to marketing (Table 3), and other strategies in the literature will be included under these categories.

\subsubsection{Defensive Strategies}

Ries and Trout (2005) asserted that defensive strategies should be used by market leaders that wish to prevent strong maneuvers by their competitors. These are designed to protect the market share of the corporation, to sustain its profitability and positioning (Bogdan et al., 2008). According to this view the market leader that adopts defensive strategies will defend itself against competitors and strengthen its own position by preventing new threats (new products, new promotional activities and additional services), while it forces its competitor to exhaust its valuable resources (Garsombke, 1987). The six defensive strategies that have been adapted to marketing from military literature are position defense, mobile defense, pre-emptive defense, flank positioning defense, counteroffensive defense and strategic withdrawal. The defensive strategies shown in Figure 1 are summarized below (Kotler and Singh, 1981; Tek, 1999; Kotler and Keller, 2009).

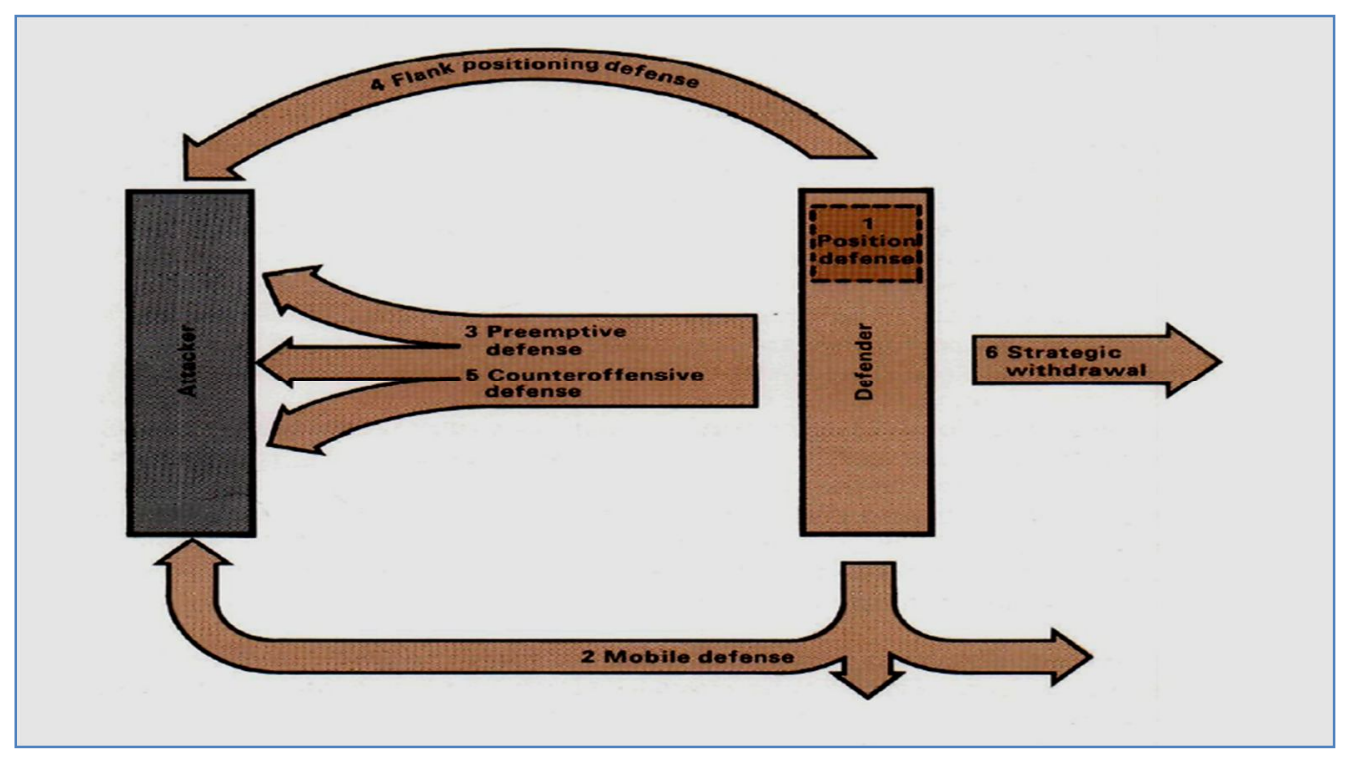

Figure 1. Defense Strategies

Source: Kotler, P. and Singh, R. (1981). Marketing Warfare in the 1980s. Journal of Business Strategy, 1(3): 30-41.

Position Defense: The conventional concept of defense is closely related to the reinforcement of the fort. Almost all forts in history have failed in war situations. This strategy is one of the most risky military strategies. The best counterpart to this concept in the business world is marketing myopia. According to this view, the biggest mistake that a powerful brand can make is to believe that growth and profitability will continue. The biggest mistake that a market leader under attack can make is to use all its resources to reinforce the fort around its existing products. According to 
this view, the best approach for firms that want to avoid this mistake is to reduce risk by expanding towards similar or different fields.

Mobile Defense: Mobile defense is expansion towards new fields that the firm can use for defense or counteroffensives in the future. This expansion is done through market expansion and diversification rather than by increasing the number of brands.

Pre-emptive Defense: Pre-emptive defense is based on the principle that prevention is more advantageous than fighting, and it includes many offensive strategies. For instance, a firm can block a competitor whose market share is rising by finding its weaknesses or by encircling it. Another example of this strategy is market leaders blocking their competitors with new technologies.

Flank Positioning Defense: Flank positioning defense is creating a blockade that will stop the enemy. In this strategy potential threats should be carefully analyzed, and flanks should be reinforced accordingly. It is easy to find examples of firms (eg. Coca Cola) that use flank positioning defense in the business world. The firm launched diet coke before Pepsi Cola and gained power in this segment before its competitor could. The leader of the razor blade market, Gilette, entered the female products market and got an edge over competitors that entered the market later.

Counteroffensive Defense: This is the counteroffensive reaction of the party that is in the defensive position. For instance, when Oxy-5 reinforced its acne medication with powerful promotional activities, Clearasil responded by increasing its promotional activities. Sometimes when the market share is being lost too fast, it is obligatory to respond with counteroffensives. When Gilette gained power in the Turkish market, Derby responded counteroffensively with an intense marketing campaign using its newly created Ali Desidero character.

Strategic Withdrawal: Strategic withdrawal, which is considered to be neither offense nor defense by certain sources, is a maneuver where a firm can focus on important points in order to secure its market power and to be able launch counteroffensives. For instance, Westinghouse used the strategic withdrawal strategy by reducing the number of its refrigerator models from 40 to 30 .

\subsubsection{Offensive Strategies}

Offensive strategies are used by challenger firms to increase their market share (Bogdan et al., 2008). These are usually recommended for second and third ranking firms in the market. In this strategy the challenger firm finds the Achilles heel of the leader and attacks this point with full force. This offensive strategy is based on finding the weakness of the leader, rather than a head on collision. The leader's weakness can be in a range of fields from product features to consumer service. The challenger can improve its product with new features or try to offer better customer service (Garsombke, 1987). Offensive strategy types are frontal attack, flanking attack, encirclement, bypass attack and guerilla warfare. The offensive strategies shown in Figure 2 are summarized below (Kotler and Singh, 1981; Tek, 1999; Kotler and Keller, 2009). 


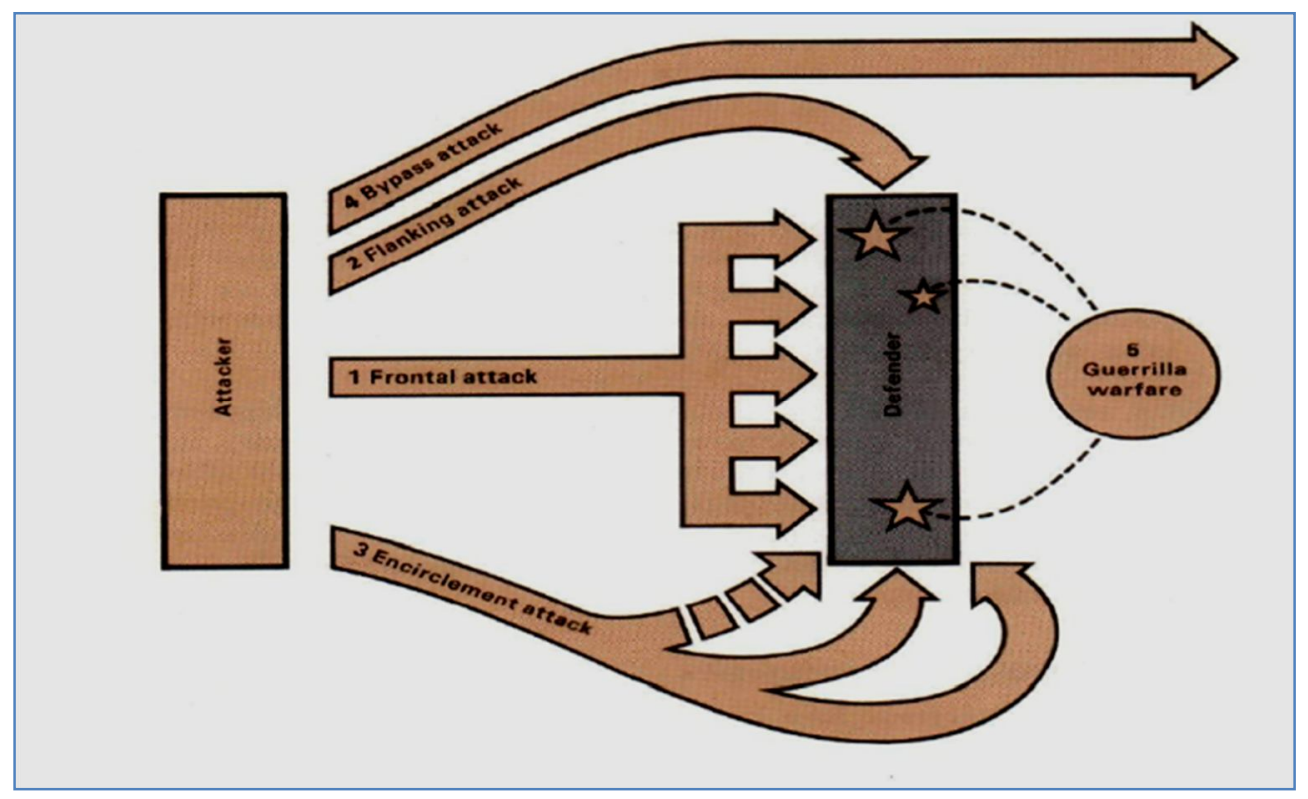

Figure 2. Offensive Strategies

Source: Kotler, P. and Singh, R. (1980). Marketing warfare in the 1980's. Journal of Business Strategy, 1(3): 30-41.

Frontal Attack: In a frontal attack the challenger attacks the leader's front lines with full force. The aim is not the weak side, but the strong side of the competitor. In order for this strategy to be successful the offensive party must have an absolute advantage over its competitor. According to military doctrine, possessing three times more power than the competitor is necessary for successful frontal attack. For instance, GE and Xerox overlooked IBM's powerful defense and failed in their frontal attack. Firms that use this strategy mostly choose to do so with low pricing. Another method is to invest in $\mathrm{R} \& \mathrm{D}$ in order to lower production costs.

Flanking Attack: The strongest point of an army in the battlefield is the point where it will attack or where it expects to be attacked. Flanks and sides are naturally weak, therefore they are the best places to attack. In modern offensive warfare the main principle is to focus power on the weak side. This strategy is especially appropriate for firms with more limited resources than their competitor. Flanking attacks can be applied on two strategic dimensions. The first is to attack geographical areas where the competitor is absent, and the second is to attack market segments that the competitor is not providing for. Flanking attacks are one of the strongest traditions of modern marketing philosophy and have a higher chance of success than frontal attacks.

Encirclement: In flanking attacks places where the competitor is absent are targeted, while in encirclement the competitor is approached from multiple directions. The aim is to attack the competitor from multiple points in order to make it defend itself on all sides. An example of this strategy is Seiko's attack from every direction by producing various models. If the competitor does not leave any points to attack, or these points are not created, flanking attack turns out to be a frontal attack and three times more power than the competitor is required. 
Bypass Attack: Bypass attack is most indirect attack at the competitor and it is similar to cold war during peace. Here we are talking about skipping the enemy, attacking easier territories and developing these areas. This kind of attack in marketing can manifest itself as diversification in unrelated products or entering new markets with existing products. This strategy was used successfully in 1971 when Colgate abandoned its domestic market, entered new markets, and added new products to its line in order to compete with Proctor \& Gamble.

Guerilla Warfare: Guerilla warfare is a good strategy for firms that are challenging, but have limited resources. In this strategy small, intermittent attacks are organized against different aspects of the enemy in order to disturb and demoralize the competitor. Traditional and untraditional guerilla warfare methods are used to disturb and wear out the competitor. The first person bring this up in marketing was Jay Conrad Levinson. Levinson (1985) asserted that a firm should focus its energy and resources on customers rather than competition and described various methods for small and medium firms to influence potential customers. This strategy manifests itself in the business world as selective price reductions, intervening in suppliers, pressuring the management, intense promotional attacks and legal action towards the competitor. The strength of guerilla warfare stems from (Garsombke, 1987):

- The guerilla preserves its resources since the competitor is never confronted.

- Guerilla power is very flexible and can be adapted to both offensive and defensive operations.

- It is difficult to respond to guerilla warfare with classical methods.

Consequently, guerilla strategies are suitable for small firms with high flexibility and limited resources. A small firm can easily withdraw from the market or change its product line and management objectives (Bogdan et al., 2008).

\subsection{The Most Effective Military Strategies in History}

The four most effective military strategies in history according to internet sources; crescent, shock and awe, blitzkrieg and guerilla warfare are found scattered in academic sources. All of them are offensive. Guerilla warfare is found in many sources on military strategy, while the other three are not found in main sources. Nevertheless they are also described below for being complementary.

Crescent Strategy: The fundamental strategy, especially in Eastern societies, the crescent tactic survived until the modern age. Requiring a high level of war analysis for that period, this tactic was especially successful against bulky armies. It was favored by mounted, swift moving armies with light armor, such as Mongolian and Turkish armies and the first close encounter was between troops at the center. After harsh clashes, these centrally located troops would withdraw in mass, and organized groups would encircle the enemy army that attempts to pursue them, creating a crescent shape. This strategy is based on pretending to escape in order to draw the enemy into an ambush and encircle them. The first users of the crescent strategy were the Scythians (Kafesioğlu, 1989). In the eighteenth century this strategy was gradually replaced with European tactics (Çnar, 2014). This strategy has important similarities with the encirclement strategy, a basic military strategy.

Shock and Awe: Formalized by Ullman and Wade (1996), this doctrine is based on terrifying the enemy to destroy its will to fight with an overwhelming power. Shock and awe is based on the idea that excessive and sudden use of force 
will scare and baffle the enemy. This strategy is more effective in frontal attacks. The counterpart of this strategy in marketing can be to conduct intense marketing communication with big budgets from many channels or sudden price reductions.

Blitzkrieg: Blitzkrieg is very similar to shock and awe (Ullman and Wade, 1996). The main military tactic of ponderous armies, it was used successfully in World War II by the Nazi army. This strategy seems to be more suitable for frontal attacks.

\section{Discussion}

The defensive and offensive strategies in the military literature have been adopted by the marketing literature as strategies that can be utilized by leader or challenger firms. Although there are not any studies on the relationship between some of the prominent models and approaches in the strategic marketing field and military strategies, there are some studies that refer to these concepts.

Product Life Cycle and the BCG Matrix: Coined by Joel Dean in 1950 and later developed by Levitt (1984), product life cycle is the basis of many marketing studies. Based on the idea that products have a life cycle just like living things, the life cycle of a product consists of four stages: introduction, growth, maturity and decline. A matrix developed by Boston Consulting Group in 1968 for portfolio analysis was a model for determining the market position of products and is parallel to product life cycle strategies. In this matrix products are categorized as question marks (during introduction to the market), stars (during growth), cash cows (during maturity) and dogs (during decline). When strategies that can be utilized by firms in these areas are considered together with defensive and offensive strategies we conclude that offensive strategies can be used during introduction and growth, defensive strategies can be used during maturity and defensive and withdrawal strategies can be used during decline. Obviously, offensive strategies to be used during the introduction and growth periods will differ according to the competitive environment. If there is no competition during the introduction period, the target of the attack will be customers rather than the competitors, the logical target if there is intense competition (Kotler and Keller, 2009).

Segmentation and Positioning: Segmentation was identified in 1956 by Smith, and positioning was identified in 1969 by Jack Trout. Segmentation relates to the identification of appropriate market segments for firms, and positioning means trying to position the product/brand in a different place than the competitors (Trout, 2005). Preemptive defense and flank positioning defense, as well as encircling and bypass attacks, are military strategies that can be used for targeting appropriate segments in the market.

Product/Market Development Strategies: In 1957 Igor Ansoff prescribed four strategies for firms that aim to grow: market penetration, product development, market development and diversification. Firms can use product/market development and diversification strategies in mobile defense, when they gain power in different sectors and in bypass attacks when they bypass the market where the competition is strong and go for other markets. 
Basic Competition Factor and Generic Strategies: The terms threat, battlefield and competition were used in 1980 by Michael Porter to talk about competition factors, and to reflect on the relationship between marketing and military literature. The competitive environment that is shaped by competitors, suppliers, new entrances to the market, replacement products and threats from customers has similarities with the threats in a war situation.

\section{Conclusion}

The military strategies described in this study are meant to offer new perspectives and guidance to marketing managers in today's intense competitive conditions. There are other military strategies and tactics that are not included in this study and can be used by marketing experts as well. With the proliferation of interdisciplinary studies, military history and military strategies may be analyzed by marketing scholars with different perspectives. For some it is obvious that in marketing warfare, where the market is the battleground, competitors are enemies and CEO's are generals, traditional marketing weapons need to be used more strategically. At this point we believe that military literature can offer guidance to marketing experts. In further research, cyber warfare in military literature and digital marketing can be linked and researched.

\section{References}

Bogdan, C.G., Gabriela, C.L., Alina, C. (2008). To the edge of marketing warfare. Applying military strategies in a company from the mobile Telecommunication sector in Romania. Annals of the University of Oradea, Economic

Science Series, 17(4): 155-159.

Clausewitz, C. (1989). On War. Princeton University Press.

Çınar, B. Savaş Tarihinde Saldiri Savunma İlişkisi, http://www.paradoxfan.com/forum/index.php?topic=3667.0, Access: 07.02.2014.

Ergen, A. (2011). Stratejik Düşünce Yaratma: Mavi Okyanusa Yelken Açma, Pazarlama ve Pazarlama Araştırmaları Derneği Dergisi, 4(7).

Garsombke, T.W. (1987). Military Marketing Warfare: A Comparative Review of the Use of Combative Philosophies and Terminology, Journal of Marketing, 51(1), 135-138.

Ho, S.K., Choi, A.S.F. (1997). Achieving marketing success through Sun Tze's Art of Warfare. Marketing Intelligence \& Planning, 15(1): 38-47.

Ilıcak, G., Özgül, R. (2005). Sun Tzu Savas Sanatina Gore Marka Pazar Stratejilerinin Belirlenmesi. Journal of Kultur University, 1, 95-105.

İslamoğlu, A.H. (2008). Pazarlama Yonetimi. Beta Basim A.S.

Kafesoğlu, İ. (1989). Turk Milli Kulturu. Bogazici Yayinlari, Istanbul.

Keith, R.J. (1960). The Marketing Revolution. Journal of Marketing, 24(3): 35-38.

Kotler, P., Singh, R. (1981) Marketing warfare in the 1980's, Journal of Business Strategy, 1(3): 30-41.

Koçel, T. (2010). Işsletme Yöneticiliği, Beta Yayınları.

Kotler, P., Keller, K.L. (2009). Marketing Management. Pearson Education, 13th ed. 
Levinson, J.C. (1985). Guerrilla Marketing. Houghton Mifflin Harcourt Publishing Company.

Levitt, T. (1984). Marketing myopia. Journal of Library Administration, 4(4): 59-80.

MacDonald, J. B., Neupert, K. E. (2005). Applying Sun Tzu's terrain and ground to the study of marketing strategy. Journal of Strategic Marketing, 13(4), 293-304.

Moriya, H. (2008). The 36 Secret Strategies of the Martial Arts: The Classic Chinese Guide for Success in War, Business and Life, Kodansha International.

Oxenfeldt, A.R., Moore, W.L. (1978). Customer Or Competitor: Which Guideline For Marketing?. Management Review, August, 43-48.

Porter, M. (1996). What is Strategy?, Harvard Business Review, November-December.

Pheng, L.S., Sirpal, R. (1995). Western Generic Business and Corporate Strategies: Lessons from the Thirty-Six Chinese Classical Strategies. Marketing Intelligence and Planning, 13(6): 34-40.

Ries, A. and Trout, J. (2005). Marketing Warfare. McGraw-Hill Companies.

Tarihin En Etkili 4 Askeri Stratejisi, Anonymous, http://www.frmtr.com/tarih/3142444-tarihin-en-etkili-4-askeristratejisi.html, Access: 07.02.2014.

Tek, Ö.B. (1999). Pazarlama İlkeleri, Global Yönetimsel Yaklaşım Turkiye Uygulamalaii. Beta Yayınları, İstanbul. Tino, R. (1987). Marketing warfare by Al Ries and Jack Trout, McGraw Hill Book Company.

Trout, J. (2005). Konumlandırma Stratejileri, Optimist Yayınları, Istanbul.

Ullman, H.K., Wade, J.P. (1996). Shock and Awe. Prepared by Defense Group Inc. For The National Defense University, http://www.dodccrp.org/files/Ullman_Shock.pdf, Access: 07.02.2014. 